\title{
アルミニウムの加工硬化，固溶硬化，析出硬化に ともなう振動減衰能の変化
}

\section{浅野滋 天木友士*}

\author{
名古屋工業大学材料工学科
}

J. Japan Inst. Metals, Vol. 66, No. 2 (2002), pp. 109-116

(C) 2002 The Japan Institute of Metals

\section{Change in Damping Capacity of Aluminum as a Result of Work Hardening, Solid-Solution Hardening and Precipitation Hardening}

\author{
Shigeru Asano and Yushi Amaki*
}

Department of Materials Science and Engineering, Nagoya Institute of Technology, Nagoya 466-8555

A data treatment procedure is formulated for quantitative evaluation of the amplitude dependence of the damping capacity and applied to the decaying process of elastic resonant vibration for aluminum and its alloys. Pure aluminum exhibits a very high damping capacity with characteristic amplitude dependence, which is almost equivalent to that of pure magnesium, a well-known high-damping metal. Work hardening of pure aluminum suppresses the damping capacity in general, although a slight initial strain appears temporarily to enhance it.

Upon the addition of 0.8 at $\% \mathrm{Mg}$ to aluminum, solid-solution hardening considerably suppresses the damping capacity, and work hardening of this dilute alloy reduces it further. Meanwhile, upon the addition of 0.7 at $\% \mathrm{Fe}$ or 0.7 at $\% \mathrm{Ni}$ to aluminum, precipitation hardening moderately suppresses the damping capacity, but work hardening of these alloys enhances it. These phenomena can be explained in terms of short-range dislocation motion that synchronizes with the elastic resonant vibration of specimens. High-damping alloys with sufficient strength and ductility can, in principle, be designed by work hardening of the precipitation-hardened alloys with no solid-solution-hardened matrix.

(Received October 29, 2001; Accepted January 7, 2002)

Keywords: damping capacity, amplitude-dependent internal friction, work hardening, solid-solution hardening, precipitation hardening, aluminum alloy

\section{1. ま え がき}

材料を実際に使用するとき，その材料自身の内部摩擦を利 用して，振動や騒音を抑制しようとする技術がある．との際 に用いられる材料は, 一般に制振材料または高減衰能材料と 呼ばれている. 従来から各種の高減衰能材料が開発されてき たが, いずれも強度や勒性, 加工性に問題があり, その用途 は特殊分野に限定されている. 高減衰能材料の強度を向上さ せようとすると, その減衰能は大幅に低下することが経験的 に知られている1,2). つまり, 高強度と高減衰能は両立不能 の関係にあるようである. しかし, 強度向上を実現する方法 は，いくつかの独立なメカニズムにもとづいているが，必ず しもメカニズムごとに, 強度と減衰能の相互関係が明らかに されているわけではない, そのため, 適切な強度を保ちなが ら, 必要な減衰能を有する材料の開発原理は, 十分に確立さ れていないのが現状である.

材料の機械的性質のうち強度や勒性, 加工性は, 材料内部

\footnotetext{
* 名古屋工業大学大学院生, 現在 : 陎本田技術研究所 (Graduate Student, Nagoya Institute of Technology, Present address: Honda R \& D Co. Ltd.)
}

における転位の増殖過程と長距離の集団運動によって支配さ れる.これに対して, 材料の減衰能のうち転位に起因するも のは, 運動転位の密度と短距離往復運動の易動度によって決 定される ${ }^{3)}$ 。この場合の減衰特性は, 実験室において, 内部 摩擦の振幅依存性の測定から評価される。しかしながら，振 幅に依存する場合の内部摩擦の絶対值に関しては, 測定原理 においても物理的意味においても, 従来の研究方法にはきわ めて不正確な点が残されている. 前報3)において, 高減衰能 金属とされるマグネシウムを例にして，この問題を検討して 方法論の修正を試みた。

アルミニウムとその合金は, 安価で軽量のうえ加工性が優 れて抢り，また，合金化や時効処理によって，適切な強度を 容易に実現できるという点で，人間にとって最も利用しやす い金属である，そのため，転位に起因する内部摩擦について 古くから研究されてきたが, わが国だけにかぎっても, 多く の系統的な実験結果が報告されている4-7). しかし，高減衰 能材料としては，いくつかの開発努力が行われてきたが8), 大規模な実用化には至っていない。一般に純金属は，その内 部で活発な転位運動が起こるので, 強度は低いが減衰能はき わめて高い。これはアルミニウムでも同様であり, 高減衰能 金属とされるマグネシウムにも匹敵する減衰能を示す 3 . 
そこで本研究では，市販の純アルミニウムを取り上げ，各 種の強化法を施して，その強化法ごとに強度と減衰能の変化 を測定し，その相互関係をくわしく検討する．その際，内部 摩擦の振幅依存性については, 従来の測定法の不備を修正し て，十分に信頼度の高い測定データを得るよう注意する．ア ルミニウムについて，強度と減衰能の相互関係を実験的に明 らかにした後, 一般の金属材料について，実用上の問題とし て勒性や加工性を維持しつつ, 使用目的に応じた減衰能を実 現するための基本原理について考察する.

\section{2. 実 験 方 法}

\section{1 実験材料の選択と測定法}

本研究の目的は, 減衰能を向上させる原理の考察であり, また，減衰能を評価する方法論の検討である，そのため，実 験材料としては新規な物質ではなく，転位に起因する内部摩 擦について，以前から測定結果が報告されているアルミニウ ムとその合金を選択した。これらは高減衰能材料としての実 績はあまりないが1,2)，通常材料としては広く利用されてお り，強度や勒性，加工性を制御する技術もほぼ確立されてい るからである，用いたアルミニウムは，実用化への配慮から

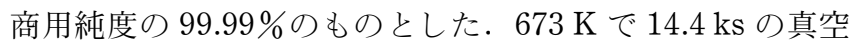
焼鈍を施した後，炬内で徐冷した状態を出発材料とした。強 度向上のために加工硬化, 固溶硬化, 析出硬化の 3 種類の 強化法を実施して，それぞれ強度と減衰能の変化を測定した。

まず加工硬化に関しては，室温において曲げ変形，引張り 変形, 圧延変形により塑性丕を与え, 強度の目安としてビッ カース硬度を測定した．つぎに固溶硬化に関しては，合金元 素として Mg を選び，上記の焼鈍状態と加工状態で，強度 および内部摩擦を測定した。なお，この $\mathrm{Al}-\mathrm{Mg}$ 合金の内部 摩擦の振幅依存性については，以前にわれわれが系統的デー タを報告している6)。さらに析出硬化に関しては，合金元素 として $\mathrm{Fe}$ と $\mathrm{Ni}$ を選び，やはり上記の焼鈍状態と加工状態 で，強度および内部摩擦を測定した。ここで $\mathrm{Fe}, \mathrm{Ni}$ を選ん だ理由は, 比内ら ${ }^{4,5)}$ が加工状態の内部摩擦について, 系統 的データを報告しているからである.

内部摩擦の測定は，約 $900 \mathrm{~Hz}$ で両端自由の横振動方式に より行い, 室温, 真空中において自由減衰過程で振幅の時間 変化を実測して，以下に述べる方法により対数減衰率を評価 した。ここで採用したオーディオ領域の振動数は，材料の使 用現場において，機械振動による騒音や疲労などの実害をも たらす可能性がある実験条件である.

\section{2 内部摩擦の測定原理の再検討}

前報3)において，内部摩擦の振幅依存性に関する測定原理 のなかにある問題点を指摘し，通常の方法に対する修正を試 みた。 そこで本報では，高減衰能材料をさらに一般化して取 り扱い，特に実験方法と適用条件について，原理的観点から 再検討することにする。一般に固体材料の減衰能は，振動工 ネルギー $W$ に対して，振動変形の 1 周期の間に熱転化する エネルギー $\Delta W$ の比率として物理的に定義されている.こ れは内部摩擦と呼ばれる物理量であるが， $\Delta W$ を直接的に
測定することは，原理的にも技術的にもきわめて困難である.

そこで実際上は, 固体材料の弾性的共鳴振動を利用して, 外部環境との力学エネルギーの交換をできるかぎり遮断し, 力学エネルギーの損失の度合いを測ることを目指して，いろ いろな測定操作が工夫されている. そのため, 内部摩擦の測 定值については, 多数の操作的定義が併存して使用されてい る。例えば, 自由減衰過程の対数減衰率 $\delta$ や共振曲線の広 がり $Q^{-1}$, 応力と歪の位相差 $\phi$, などである. これらの測定 值は，いずれも内部摩擦と呼ばれて混乱する場合も時にある が，そのような用語が許容されるのは, 内部摩擦が小さい場 合にかぎって，エネルギ一原理にもとづく減衰能に対して， 次に示す比例関係が成り立つからである.

$$
\Delta W / W=2 \delta=2 \pi Q^{-1}=2 \pi \phi
$$

このような比例関係は，いずれの成書9,10)でも説明されてお り, また, 制振材料に関する JIS の用語解説も, その前提で 記述されている。

しかしながら，ここには二つの重大な問題が残されてい る. まず第 1 は, 高減衰能材料のなかには, 減衰能が $10 \%$ を越えて $80 \%$ に近い值も報告されていることである1,2)。つ まり, 内部摩擦が小さいという前提が満たされていない場合 があり，そのような場合には，式 (1)の比例関係を厳密な 理論表現に修正して，かなり複雑な手続きによって減衰能を 算出しなければならない。第 2 の問題は，多くの高減衰能 材料に打ける内部摩擦が振幅に依存することである。つま り, 測定值の操作的定義は, 線形の力学応答を前提とするも のであるが, 内部摩擦の振幅依存性は, 非線形の力学応答に もとづく現象であって, 式 (1)に現れる測定值は減衰能を 除いて，それぞれの物理的意味を失ってしまう.

なお，本研究のアルミニウムおよびその合金では，対数減 衰率の測定值がいずれも 0.05 以下であって，その場合の減 衰能の算出誤差は，式（1）によっても 1 割を越すことがな い。したがって，これは実際の測定精度の範囲内にあるの で，本報に抢いては，内部摩擦の絶対值に関する第 1 の問 題点を留保したまま, 対数減衰率の意味づけは式 (1)をも とにして, 内部摩擦の絶対值の振幅依存性に関する第 2 の 問題点のみを再検討する。

固体材料の弾性的共鳴振動の自由減衰過程において，振動 体上の定点の変位振幅 $A$ は, 時間 $t$ の関数として, 次のよ うに表現される。

$$
A(t)=A_{0} \exp (-f \delta t)
$$

ここで， $A_{0}$ は自由減衰を開始した時点における変位振幅で あり, $f$ は振動数である. 式 ( 2 )のなかの $\delta$ が対数減衰率 で, 内部摩擦を表す尺度の一つであり，この場合の減衰能は 式（1）によって，2 $\delta$ をパーセントで表した量とされてい る. 内部摩擦に振幅依存性がない場合には， $\delta$ は定数であっ て, 1 回の自由減衰過程で $A$ の時間変化を測定すれば, 対 数減衰率の絶対值を一意的に決定することができる．この場 合は，測定原理のうえで何の問題もない.

ところが内部摩擦に振幅依存性がある場合には， $\delta$ が定数 ではなく振幅の関数であるので, 1 回の自由減衰過程におい て，Aが $t$ とともに減少すれば，それにともなって必然的に $\delta$ の值も変化する。そのため, 内部摩擦の振幅依存性が顕著 
な場合には，1個の対数減衰率の絶対值を一意的に決定する ことができない。つまり, 1 回の自由減衰過程のなかに, 内 部摩擦の振幅依存性に関する情報がすべて含まれているの で, 特に歪振幅の関数として表された対数減衰率の評価につ いては, 実験変数と実測值の物理的意味を明確にしておく必 要がある.

まず，振幅を表すための実験変数は，振動体上の定点の変 位振幅 $A$ ではなく, 内部の変形状態を表すために, 原理的 には歪振幅 $\varepsilon_{0}$ とする必要がある. ところが弾性的共鳴振動 に抢いては, 歪が均一に分布しないので, 歪振幅 $\varepsilon_{0}$ は振動 体の内部で位置の関数となる. そこで, 振動変形の度合いを 表現するため, 実際の実験変数としては, 歪振幅の最大值 $\varepsilon_{\max }$ を採用する慣行がある.すなわち, 弾性的共鳴振動にお ける歪振幅は, 次のように位置座標を用いて表現される.

$$
\varepsilon_{0}(x, y, z)=\varepsilon_{\max } \varphi(x, y, z)
$$

ここで, $\varphi$ は最大值が 1 となるよう規格化された歪分布関数 であって, 実際の振動様式からきまる既知関数である ${ }^{11,12)}$. この場合, 実験変数 $\varepsilon_{\max }$ は次の関係によって, 実際に測定 される変位振幅 $A$ から算出される.

$$
\varepsilon_{\max }=C A(t)
$$

ここで, $C$ は弾性論にもとづいて, 振動様式からきまる既知 の定数である.すなわち, 自由減衰過程においては, 実験変 数が時間の関数であることに注意する必要がある.

つぎに，対数減衰率の実測值に関しては，以下のような問 題がある. 弾性的共鳴振動における歪振幅が式 (3)で表さ れる場合, その振幅依存性を表現する $\delta\left(\varepsilon_{0}\right)$ は, 振動する試 料の内部で必然的に位置の関数となる. しかしながら， $\delta$ を 位置ごとに測定することは原理的に不可能であって, 実際に 測定される対数減衰率は, 試料全体の振動状態からきまる平 均值を意味する。そこで以下では，平均を表す添字によっ て, 実際の測定值を $\delta_{\mathrm{av}}$ と記すことにする. 本研究のオーデ ィオ振動数においては, 振動体上の定点の運動を電気信号に 変換すれば，交流測定の原理により，振幅の時間変化を示す 式（2）は容易に連続曲線として実測できる。したがって， 対数減衰率の実測值は, 式 $(2)$ にもどいて, 次式から正 確に決定することができる.

$$
\delta_{\mathrm{av}}=-\frac{1}{f} \frac{\mathrm{d}}{\mathrm{d} t} \ln A(t)
$$

このような手順によって, 内部摩擦の振幅依存性を評価する 場合には, 実測された $\delta_{\mathrm{av}}\left(\varepsilon_{\max }\right)$ の絶対值について, その物 理的意味はきわめて単純である.すなわち, 式 (4) と式 ( 5 )は, $t$ を媒介変数として, 実測值の物理的意味を具体化 したものである. 弾性的共鳴振動を利用する測定において は, 歪振幅が位置の関数であるため, 材料固有の内部摩擦と しての $\delta\left(\varepsilon_{0}\right)$ は, 直接的には実測できないことに注意する必 要がある. 対数減衰率の実測值と材料固有の内部摩擦の関係 については, 後節に掞いて考察するとともに, 従来の文献を 批判的に検討する.

\section{3. 実 験 結 果}

\section{1 純金属における加工硬化}

まず，アルミニウムの焼鈍状態において，前節で述べた方 法によって内部摩擦の振幅依存性を測定した. Fig. 1 は，歪 振幅の最大值に対して, 自由減衰過程における対数減衰率の 変化を示すものである. 試料の励振を開始してから $60 \mathrm{~s}$ 以 上経過して, 弾性的共鳴振動が定常化した後, 励振を停止し て, 自由減衰過程の振幅変化から式 (2)を連続的に測定し た.さらに, コンピューター処理によって, 式 (4) と式 (5) から内部摩擦の振幅依存性を評価した. なお, 図中の ○印は励振を停止し, 自由減衰の開始時点における対数減衰 率であり，○印をつなぐ矢印は，強制振動の定常状態におけ る内部摩擦の振幅依存性に相当する.このような定常振動に おける内部摩擦は，振動系の減衰特性を支配するものである が，振幅依存性がある場合は，実験変数を指定しないかぎ り，減衰能の值を決定することができない。

Fig. 1 の実験結果の場合, $\varepsilon_{\max }=1.5 \times 10^{-5}$ の定常振動に おける対数減衰率は $3.6 \times 10^{-2}$ であり，減衰能に換算すれば 約 $7 \%$ となる.これは出発材料の $\mathrm{Al}$ の潜在能力を示すもの で，Fig. 1 の結果から判断すれば，その減衰能の值は丕振幅 の増加とともにさらに増大するものと期待される。なお，上 に示した減衰能の值は，高減衰能金属といわれる $\mathrm{Mg}$ の測 定值に匹敵するもので，活発な転位運動が起こる純金属であ るかぎりは，FCC 金属や一部の HCP 金属でも同様の值が得 られる ${ }^{3)}$. また，大きな歪振幅の場合には，自由減衰過程に おける内部摩擦の振幅依存性は, 定常振動にお打る内部摩擦 の振幅依存性と著しく異なることがわかる．これは後者がお もに運動転位の密度に支配されるのに対して，前者はおもに 自由減衰過程における転位の運動状態の变化を敏感に反映す るからである。自由減衰の場合と定常振動の場合において，

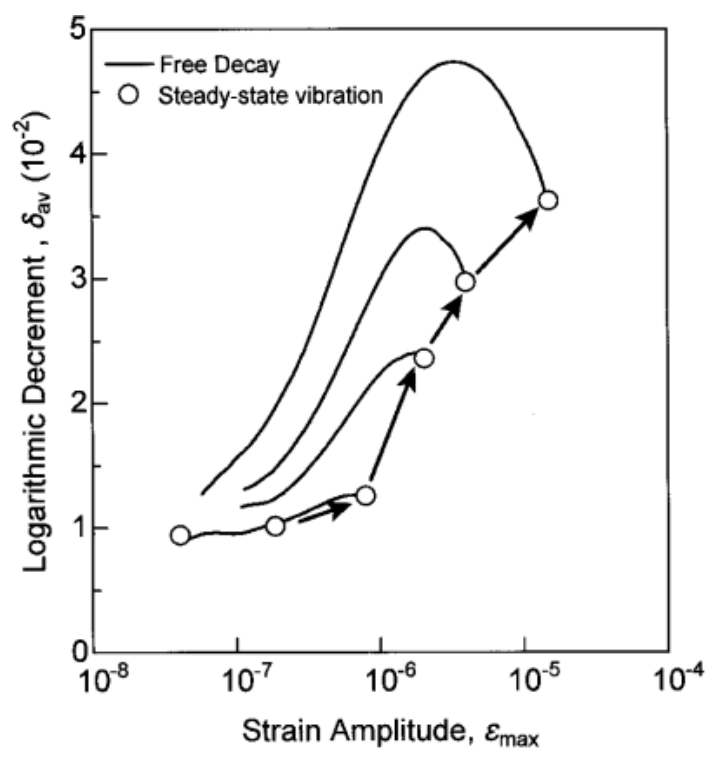

Fig. 1 Logarithmic decrement measured as a function of the maximum value of strain amplitude during several free-decay processes for pure aluminum in an annealed state. 
内部摩擦の振幅依存性の意味づけが著しく異なる点は，前 報3)において，振動変形に同期した転位の往復運動という観 点から，特に自由減衰過程に注目してくわしく考察した.

つぎに，種々の変形方法により，塑性歪を与えて加工硬化 させ，自由減衰過程における対数減衰率を測定した結果を Fig. 2 に示す。この場合，自由減衰の開始時点における歪振 幅は，ほぼ一定となるよう振動条件を調整した。この結果が 示すように，わずかな塑性丕による加工硬化の初期には，運 動転位密度の増加のため内部摩擦はいったん増加するが，全 体的にいえば，塑性歪の増加による加工硬化とともに，内部 摩擦は著しく低下して振幅依存性が緩慢になる，つまり，加 工硬化による強度向上は，転位がセル構造を形成し，材料内 部における大部分の転位がセル壁内に閉じ込められて，短距 離の往復運動も困難になるため, 大幅に減衰能の低下をもた らすものと考えられる。このような結論も，前報3で示した $\mathrm{Mg}$ の場合とほとんど同様である。なお，この場合のビッ カース硬度は，焼鈍状態で 14.3 であり，6\%圧延状態では加 工硬化によって 19.2 となった.

特に注目すべき点は, 加工硬化の初期において内部摩擦が いったん増加する現象であり，最近になって HCP 金属や BCC 金属でも報告されるようになったが3,13)，FCCの純金 属に㧧いては, 内部摩擦の振幅依存性として, 初めて正確に 検出されたものではないかと思われる。なお， $\mathrm{Al}$ のような FCC 金属は，転位運動が活発なだけでなく，前報3)で示した $\mathrm{Mg}$ の場合と異なって，すべり系の数が多いので多結晶でも 塑性変形が起こりやすく, 引張り変形や圧延変形では小さな 塑性歪を正確に与えることが困難なため，ここでは曲げ変形 に抢ける塑性歪の最大值によって代用した。加工硬化の初期 に执て内部摩擦がいったん増加する現象は, 高い減哀能を 実現するための手段として利用できる可能性がある。

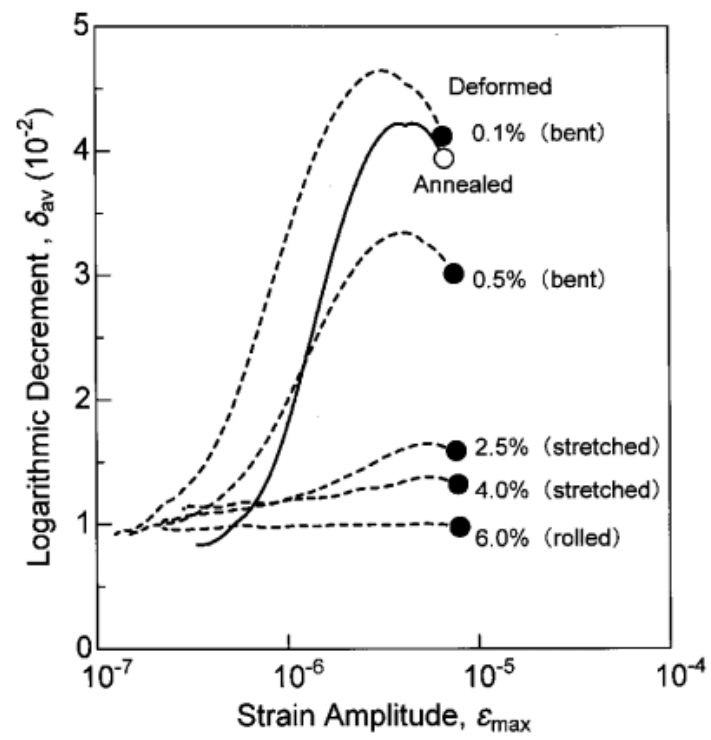

Fig. 2 Logarithmic decrement measured as a function of the maximum value of strain amplitude for pure aluminum after plastic deformation.

\section{2 合金元素添加による固溶硬化と析出硬化}

純金属のアルミニウムに対して， $\mathrm{Mg}$ と $\mathrm{Fe}, \mathrm{Ni}$ をそれぞ れ $0.7 \sim 0.8$ at\%ずつ添加した 3 種類の 2 元合金を作製し， 強度と減衰能の変化を調べた. Fig. 3 は, 純金属および 3 種 類の合金における応力一歪曲線であって，合金元素の添加に よる強度向上を示している。また，焼鈍状態におけるビッ カース硬度は, $\mathrm{Mg}$ 添加抢よび $\mathrm{Fe}$ 添加, $\mathrm{Ni}$ 添加の場合, そ れぞれ 21.9, 23.0,20.3 となり，いずれも純金属にくらべて 4 割以上の硬化を示した。これらの合金の硬度は，純金属に おける 6\%圧延の加工硬化にほぼ相当するものである.

このような同程度の硬化に対して，自由減衰過程における 内部摩擦の振幅依存性を Fig. 4 に示す. Mg はアルミニウム

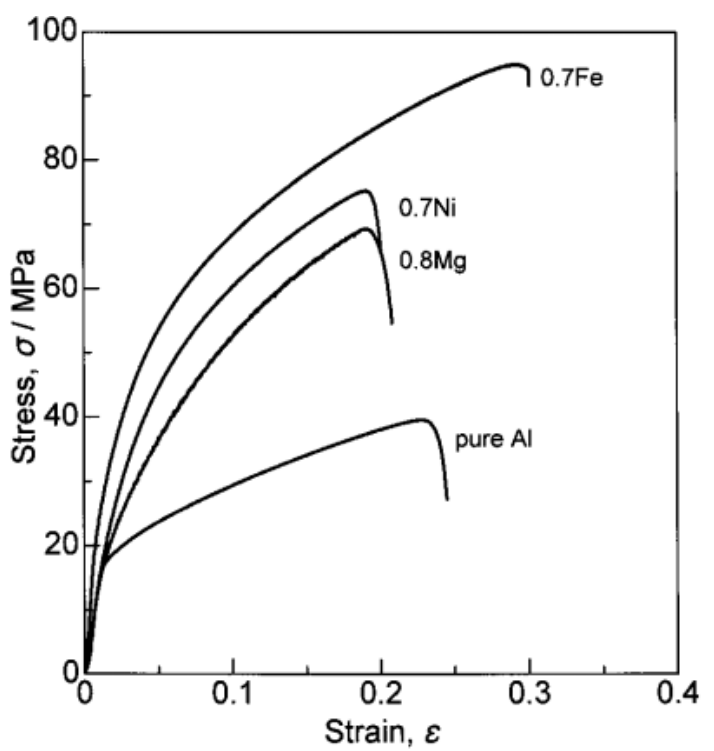

Fig. 3 Stress-strain curves for pure aluminum and A1-0.8 at $\% \mathrm{Mg}, \mathrm{Al}-0.7$ at $\% \mathrm{Fe}, \mathrm{Al}-0.7$ at $\% \mathrm{Ni}$ alloys.

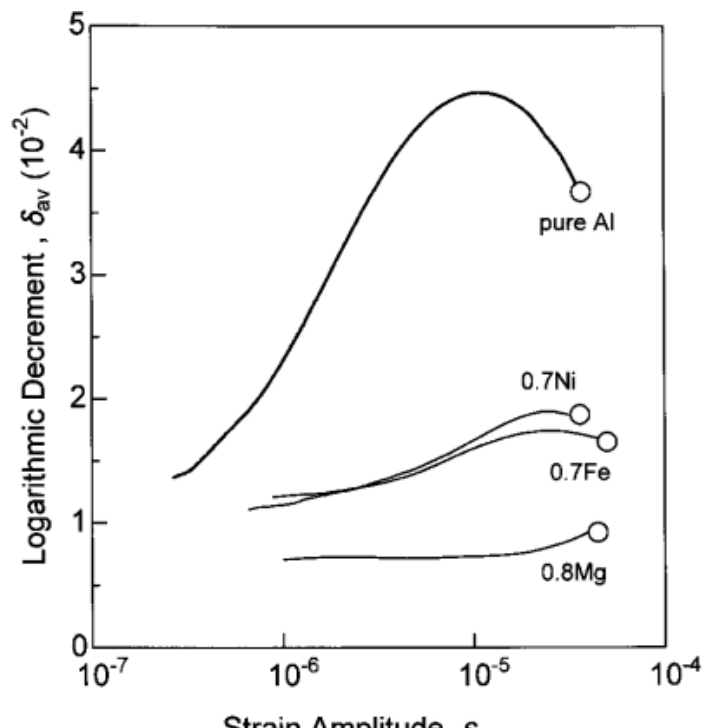

Fig. 4 Logarithmic decrement measured as a function of the maximum value of strain amplitude for pure aluminum and $\mathrm{Al}-$ 0.8 at $\% \mathrm{Mg}, \mathrm{Al}-0.7$ at $\% \mathrm{Fe}, \mathrm{Al}-0.7$ at $\% \mathrm{Ni}$ alloys in an annealed state. 
に対して，室温における固溶限が $2 \%$ ぼであり，この場合 は単相の固溶体構造である. したがって, 強化のメカニズム は単純な固溶硬化である，材料の強度向上にともなって，振 動に同期して往復運動する転位は, その易動度が低下して, 大幅に内部摩擦の低下をもたらし， $\varepsilon_{\max }=5.9 \times 10^{-5}$ の定常 振動に打減衰能は $2 \%$ 以下であった。つまり, Fig. 4 に 示す $\mathrm{Al}-\mathrm{Mg}$ 合金の結果は, 経験的に知られているように, 高強度と高減衰能の両立不能の関係を典型的に示している. なお, $\mathrm{Mg}$ の固溶濃度の増加とともに, 内部摩擦が急激に減 少し，その振幅依存性がゆるやかになる現象は，以前に系統 的データを報告したが ${ }^{6)}$, その場合も，強度の向上と減衰能 の維持が両立する濃度範囲は見いだされていない。

一方, $\mathrm{Fe}$ や $\mathrm{Ni}$ はアルミニウムに対して, 室温における固 溶限が実質的にゼロであって，この場合の合金は，それぞれ $\mathrm{Al}_{3} \mathrm{Fe}$ や $\mathrm{Al}_{3} \mathrm{Ni}$ が分散した 2 相析出構造であり，母相の $\mathrm{Al}$ はほとんぞ固溶硬化していない。したがって, 強化のメカニ ズムは単純な析出硬化である. Fig. 4 に見られるように, $\mathrm{Al}-\mathrm{Fe}$ 合金と $\mathrm{Al}-\mathrm{Ni}$ 合金においては, $\mathrm{Al}-\mathrm{Mg}$ 合金にくらべ て内部摩擦の低下がはるかに少なく， $\varepsilon_{\max }$ が上記の值であっ ても，定常振動の減衰能はいずれも $3 \%$ 以上であった。つま り, 2 相析出合金の場合は, 転位の長距離移動は析出相に妨 げられるが，短距離の往復運動に対する障害はあまり強くな いことを示している。この結果によれば，高強度と高減衰能 の両立不能の関係は, 強化のメカニズムごとに異なり，析出 硬化の場合は，相関があまり強くないと考えられる，適切な 強度を維持しながら，必要な減衰能を実現するために，この 点も手がかりになる可能性がある.

\section{3 単相合金と 2 相合金における加工硬化}

固溶硬化した $\mathrm{Al}-\mathrm{Mg}$ 合金に対して，室温における圧延変 形によりさらに加工硬化させた場合, 自由減衰過程における 内部摩擦の振幅依存性を Fig. 5 に示す。この場合は単相の

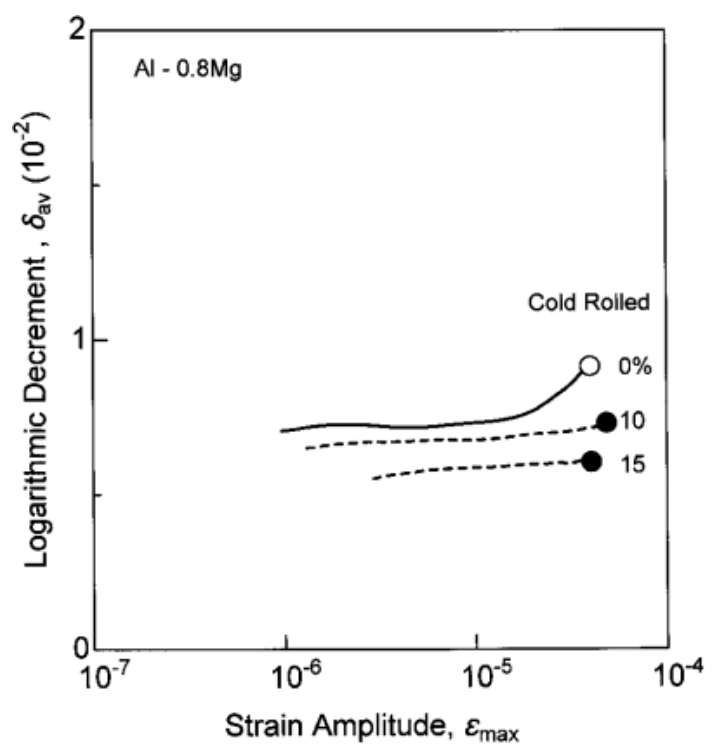

Fig. 5 Logarithmic decrement measured as a function of the maximum value of strain amplitude for the $\mathrm{Al}-0.8$ at $\% \mathrm{Mg}$ alloy after plastic deformation.
固溶体であるため, 塑性丕の増加による加工硬化とともに, 転位のセル構造が制約なく発達し, 内部摩擦はさらに低下し て，その振幅依存性もほとんどなくなった。 $15 \%$ 圧延の場 合, 定常振動における減衰能は約 $1 \%$ にすぎない. Fig. 2 に 示した純金属の場合と同様に，これは単相構造の加工硬化の 特徵を示すものといえる.

析出硬化した $\mathrm{Al}-\mathrm{Fe}$ 合金と $\mathrm{Al}-\mathrm{Ni}$ 合金に対して，圧延に よって加工硬化させた場合，自由減衰過程に抢ける内部摩擦 の振幅依存性を Fig. 6, Fig. 7 に示す. 両合金とも加工硬化 によって，内部摩擦の絶対值は増加し，その振幅依存性がゆ るやかになった。15\%圧延の場合，定常振動に抢ける減衰 能は，いずれの合金でも $4 \%$ 以上であって，自由減衰過程で もあまり低下していない。すなわち，純金属や固溶硬化合金

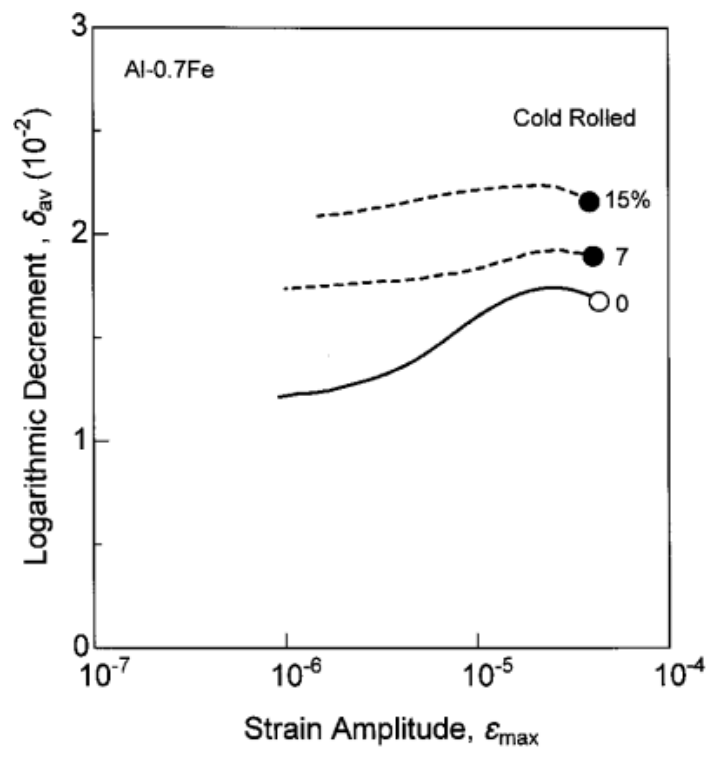

Fig. 6 Logarithmic decrement measured as a function of the maximum value of strain amplitude for the $\mathrm{Al}-0.7$ at $\% \mathrm{Fe}$ alloy after plastic deformation.

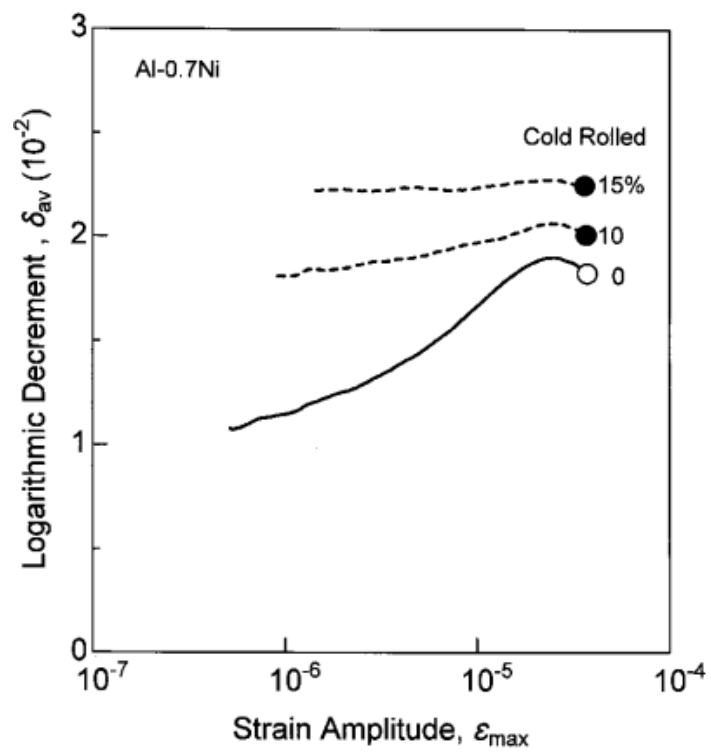

Fig. 7 Logarithmic decrement measured as a function of the maximum value of strain amplitude for the $\mathrm{Al}-0.7$ at $\% \mathrm{Ni}$ alloy after plastic deformation. 
の場合とは対照的に，固溶硬化していない母相をもつ 2 相 構造の析出硬化合金の場合は, 加工硬化による強度向上とと もに減衰能も向上する，したがって，高強度と高減衰能の両 立不能の関係は，このような特定の条件のもとでは否定さ れ，むしろその関係は逆転して相乗効果になる。

2 相構造における加工硬化の機構は，必ずしも十分に知ら れてはいないが，析出相が介在するために，転位のセル構造 の形成に大きな制約が加わり，セル壁の安定性が妨げられる ことは確かであろう。これはFig. 2 に示した加工硬化の初 期において, 運動転位密度の増加による内部摩擦の増大に対 応するものと推察される. 2 相析出合金の加工硬化という方 法は，これまでにも試みられたことはあるが4,5,14), 内部摩 擦の振幅依存性について, 十分に正確な測定結果は報告され ていない。しかし，このような方法は，高減衰能材料の開発 原理として，かなり有望なものと考えられる.

\section{4. 考察}

\section{1 転位運動にもとづく内部摩擦}

これまでの報告によれば1,2)，高減衰能材料とされる物質 は, 内部摩擦の原因によって分類され, 強磁性型, 転位型, 双晶型, 複合型, などとして知られている. 従来から高減衰 能材料の開発では，おもに高強度を目指して新規物質が探索 され，そのため，実用に際して必然的に問題化する勒性や加 工性は軽視される傾向にあった。そこで本研究では，あまり 実績はないがアルミニウムを取り上げて，転位型とされる内 部摩擦のみに着目した。それは実用化の観点から，以下に述 ベる二つの理由によっている.

まず第 1 の理由として, アルミニウムは降伏強度たけで なく, 勒性や加工性についても十分に技術的蓄積があり, こ れらの機械的性質を保証することが可能であるからである. そのような保証は，減衰能の向上も含めて，活発な転位運動 を制御することによってのみ実現される。つぎに第 2 の理 由として, 転位運動は歪振幅には強く依存するが，温度や振 動数にあまり依存しないからである。したがって, 内部摩擦 の歪振幅依存性を正確に評価するかぎりは，実用化に際し て，温度や振動数の制約をほとんど受けない。現在のとこ ろ, 一部で使われている制振鋼板は, 金属と樹脂の複合材料 であるが，このような制約が避けられない。

転位運動に関していえば，材料の強度が転位の動きにくさ を意味するのに対して，材料の減衰能は転位の動きやすさを 意味する，高強度と高減衰能について，経験的に知られた両 立不能の関係はここに起因する。しかしながら，強度と減衰 能の要因としては，転位集団の運動様式がまったく異なって いる. 強度や勒性，加工性などの機械的性質は，その機構が 完全に解明されているわけではないが，転位の増殖を含む長 距離進行移動に支配されることは確かである。これに対し て，減衰能は弾性振動に関わるので，転位の増殖を含まない 短距離往復運動によって決定される。しかし，振動変形に同 期して転位が往復運動する場合の内部摩擦に関しては，その 機構がまったく解明されておらず，これまでに提案された理 論にも，さまざまな疑問が残されている15,16).
このような転位運動では, 圧倒的に大きな弾性歪のなか に, 微小な塑性歪 $\varepsilon_{\mathrm{p}}(\sigma)$ が混入してきて, 応力と歪の関係に おいて，材料固有のヒステリシスが発現する．特に定常的な 振動変形では, 定まった形状の閉じたヒステリシス・ループ となる. そのループ面積が内部摩擦の物理的定義における $\Delta W$ であって, $\varepsilon_{\mathrm{p}}(\boldsymbol{\sigma})$ の関数形にもとづいて定式化される. 対数減衰率の $\delta\left(\varepsilon_{0}\right)$ を定式化するためには, 応力一歪曲線の なかに現れるヒステリシスの形式を規定しておかなければな らない。これまで知られている形式は 2 種類あって，それ ぞれ摩擦型および離脱型と呼ばれている15-19).

摩擦型ヒステリシスとは， 1 周期のなかに 1 個のヒステリ シス・ループが生じるもので, 弾性振動より大きな歪領域の 低サイクル疲労の実験に拈いて, 応力一歪曲線のなかでつね に観測される形式である。この摩擦型ヒステリシスを想定し， $\varepsilon_{\mathrm{p}}(\boldsymbol{\sigma})$ を任意の関数形としたまま, 現象論の枠組み12,17)を具 体的に示して, 前報3)では $\mathrm{Mg}$ に扔けるデータ解釈を行っ た、本報に打いても，いろいろな障害により抵抗を受けなが ら, 転位は振動変形に同期して往復運動するという描像にも とづいて, 前節のデータ解釈は摩擦型ヒステリシスを前提と して行った．なお， $\varepsilon_{\mathrm{p}}(\sigma)$ の関数形を任意としたまを特定し ない理由は, 転位の易動度を支配する要因がさまざまあり, すべての可能性を含めてデータ解釈を行うためである. 本研 究の範囲内でも，易動度を支配する要因は，運動転位の密度 や幾何学配置, 固溶合金原子, 析出介在物, などが考えられ る.

これに対して, もう一方の離脱型ヒステリシスとは， 1 周 期のなかに 2 個のヒステリシス・ループが発現するもの で, 転位が点欠陥による弱いピン止めから解放されたり再捕 捉されたりする素過程をモデル化した作業仮説である.これ は応力一歪曲線において実証されたことはないが，多くの専 門研究者のなかで有力な説として流布しており，制振材料に 関する JISの用語解説もその前提で記述されている．離脱型 ヒステリシスにもとづく理論はいろいろあるが，その基本形 式は，1956 年に発表された Granato と Lücke の理論であ る ${ }^{19)}$.このような理論の盲点は, 転位をピン止めするため に点欠陥の存在が必要なことであって, 点欠陥の状態により 転位の運動様式が限定され， $\varepsilon_{\mathrm{p}}(\sigma)$ の関数形が特定されてし まうことである、本研究の範囲内でも, そのような理論が適 用されるのは固溶硬化の場合だけであって, 加工硬化や析出 硬化の場合には理論の効力がない。アルミニウムに関する 小杉の研究7)によれば，固溶硬化の場合であっても，この種 の理論モデルの素過程が検知されるのは, 高純度の金属にご く微量の固溶合金原子を添加した焼鈍状態にかぎるとされて いる。また，Lebedev ${ }^{15)}$ は，離脱型ヒステリシスについて 理論的に検討し, 弾性率に関する文献データから判断して, この種のヒステリシスは発現しないと結論している.

\section{2 振動系の減衰特性と材料固有の内部摩擦}

これまでに開発された高減衰能材料では, 多くの場合は, 内部摩擦は振幅に依存するので1,2), 高い減衰能は大きな振 幅においてのみ発現する．特に転位運動にもとづく内部摩擦 は, 温度や振動数にはあまり依存しないが, 振幅に強く依存 
する，そのため，歪が均一に分布するような変形様式を採用 しないかぎり，通常の振動系では，実際の測定值と材料固有 の内部摩擦とは異なる物理的意味をもち, $\delta_{\mathrm{av}}\left(\varepsilon_{\max }\right)$ と $\delta\left(\varepsilon_{0}\right)$ とは別種の数学的関数となる.これは測定の場合だけでな く, 機械構造システムのなかに高減衰能材料が組久込まれた 振動系にも該当する. その際の問題は, 実験室の測定システ ムにおいても, 使用現場の機械構造システムにおいても, 一 般に歪は均一に分布しないので, 式 (3)で示したように $\varepsilon_{0}$ が振動系の内部で位置の関数となることである. 本論文の

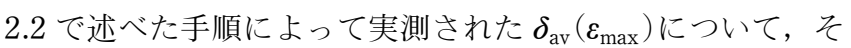
の絶対値の物理的意味が明らかな場合には, $\delta_{\mathrm{av}}\left(\varepsilon_{\max }\right)$ と $\delta\left(\varepsilon_{0}\right)$ との相互関係は, 以下のように簡単に導出される.

振動系の対数減衰率は, 式 (1) が成り立つ場合には土ネ ルギー原理から，次のように意味づけられる.

$$
\delta_{\mathrm{av}}\left(\varepsilon_{\mathrm{max}}\right)=\Delta W / 2 W
$$

そこで, 振動系内部の各位置の局所量として, エネルギ一損 失と歪エネルギーをそれぞれ単位体積あたり $\Delta w$ および $w$ と記せば，これらはいずれも位置の関数となる.したがっ て, 振動系の全体は, 次のように部分の総和として表される.

$$
\begin{aligned}
& \Delta W=\iiint \Delta w \mathrm{~d} x \mathrm{~d} y \mathrm{~d} z \\
& W=\iiint w \mathrm{~d} x \mathrm{~d} y \mathrm{~d} z
\end{aligned}
$$

ここで積分は, 振動系の全体積にわたって行われるものと し, 被積分関数は式 (3)をもとにして, 次のように表現さ れる.

$$
\begin{aligned}
& \Delta w=2 w \delta\left(\varepsilon_{0}\right) \\
& w=M \varepsilon_{0}^{2} / 2
\end{aligned}
$$

多くの場合, 弾性率 $M$ は, 振動系内部で 1 種類の定数であ るので，その場合には，式（９）は次のようになる.

$$
\delta_{\text {av }}\left(\varepsilon_{\max }\right)=\iiint \varepsilon_{0}^{2} \delta\left(\varepsilon_{0}\right) \mathrm{d} x \mathrm{~d} y \mathrm{~d} z / \iint \varepsilon_{0}^{2} \mathrm{~d} x \mathrm{~d} y \mathrm{~d} z
$$

つまり, 振動系の減衰特性 $\delta_{\mathrm{av}}\left(\varepsilon_{\mathrm{max}}\right)$ は, 式 $(3)$ に抢ける歪 分布関数に依存するものであり, 材料固有の内部摩擦 $\delta\left(\varepsilon_{0}\right)$ に対しては, 重みつきの平均値を意味する. その場合の重み とは，歪振幅の 2 乗あるいは歪エネルギーである.

したがって, 式 ( 3 ) と式(14)からわかるように, 内部摩 擦が歪振幅に依存しない場合, または歪振幅に依存しても歪 分布が一様である場合は, $\delta_{\mathrm{av}}\left(\varepsilon_{\max }\right)$ と $\delta\left(\varepsilon_{0}\right)$ が同一の数学的 関数となるが, 通常の振動系では, その条件がほとんど実現 しない. 実験室に抢ける測定システムは, 最も単純な振動系 である. 通常のねじり振子法, 縦振動法, 横振動法に対して は，任意の実測データをもとにして，材料固有の内部摩擦を 評価する方法もあるが，その算出のためにはやや面倒な手続 きが必要となる ${ }^{11,12)}$. そこで実際上は, 振幅依存性の立ち上 がり部分に着目し, 実測データに対して, 単調増加のべき関 数の実験式で近似し，きわめて簡単な手続きによって $\delta\left(\varepsilon_{0}\right)$ を評価する方法が行われる6,16).ただし, 本研究では特異な 振幅依存性の場合も含まれており, また，使用現場における 減衰能の評価という観点から, 前節では測定結果をすべて実 測したままの $\delta_{\mathrm{av}}\left(\varepsilon_{\max }\right)$ で示した。

実際の測定值と材料固有の内部摩擦との相互関係は, エネ
ルギー原理から, 式 ( 3 ) と式 (9)が成り立つかぎりは, 式 (14) として定式化される. 以前にも指摘したように ${ }^{20)}$, 理 論的根拠は単純であいまいさがなく，すでに 1940 年の Readの論文 ${ }^{21)}$ に抢いても，ほぼ同等の内容が記述されてい る.しかしながら，その後の文献のなかで，あいまいな根拠 のまま取り扱われる場合があって，必ずしも正しく批判され ていないため, 多くの研究者の間に影響が残っており, 最近 では, 減衰能の絶対值の問題が無視される傾向にある. Nowick は 1953 年の総説22)のなかで, 操作的定義のまま工 ネルギー原理によることなく, 式 (14) と等価の表現を導出 した。しかし，Nowick は導出過程が厳密にいえば正しくな いことを認めており，その後の 1972 年の成書9)では，この 問題に関する記述が全面的に削除されている。 また， Granato と Lücke は 1956 年の第 2 論文23)の付録で, 同様の 問題を取り扱ったが，何の根拠も示すことなく，対数減衰率 の実測值について, 材料固有の内部摩擦に対する単純平均之 即断し, 式(14)における重みを無視して不正確な理論式を 導出した。な掞，その理論式はすでに修正されてはいる が24,25), 本研究では $4.1 て ゙$ 述べた理由から, Granato と Lückeの理論を採用しなかった.

結局, 高減哀能材料の開発原理は, 以下のような手順にま とめられる。 まず, 実験室において素材の内部摩擦を実測し て $\delta_{\mathrm{av}}\left(\varepsilon_{\mathrm{max}}\right)$ を定め, 式 (3) と式(14)をもとにして, 材料固 有の内部摩擦 $\delta\left(\varepsilon_{0}\right)$ を評価する.この段階で本来は $\delta\left(\varepsilon_{0}\right)$ に ついて，他の素材との比較検討を行うべきものである.つぎ の段階では, 実用の機械構造システムについて, 想定される 振幅と振動様式から, 歪振幅の最大值 $\varepsilon_{\max }$ および歪分布関 数 $\varphi(x, y, z)$ を定めて, 振動系の変形様式として式 $(3)$ を決 定する.さらに，その変形様式を用いて，再び式(14)によ り, 振動系の減衰特性として $\delta_{\mathrm{av}}\left(\varepsilon_{\mathrm{max}}\right)$ を予測し, 機械構造 システムを設計する際の基礎データとする，以上は減衰能の 絶対值の取り扱いに関する原理的な手順であって，かなり面 倒な作業であるので, 何らかの簡易法やコンピューター・プ ログラムを工夫する必要があろう.

\section{5. をと め}

純金属における高い減衰能を維持しながら，強度を向上さ せる方法につき 3 種類の強化法に対して, 内部摩擦の振幅 依存性の変化を調べた.アルミニウムにおける減衰能の維持 のためには, 固溶硬化はほとんど効力がなく, 析出硬化にい くらか可能性があることがわかった。析出硬化した 2 相合 金に対しては，母相が固溶硬化していない状態で，さらに加 工硬化させることによって, 強化に加えて減衰能を向上さ せ，その振幅依存性を緩慢にすることが可能となった。

本論文の準備に際しては, 名古屋工業大学の玉岡悟司氏お よび同大学院生の西山徳人氏 (現在 : 豊田自動織機製作所) か ら多大な協力を得た. また, 本研究の一部は, 日本学術振興 会の未来開拓学術研究事業に打ける高減衰能材料開発プロシ エクトから，資金援助を受けたものである.ここに以上を記 して，感謝の意を表する次第である. 
文献

1) K. Nishiyama: Hyoumen 33(1995) 82-90.

2) F. Yin, S. Takamori, Y. Ohsawa, A. Sato and K. Kawahara: J. Japan Inst. Metals 65(2001) 607-613.

3) N. Nishiyama and S. Asano: J. Japan Inst. Metals 65(2001) 109-114.

4) M. Hinai, H. Masumoto and S. Sawaya: J. Japan Inst. Metals 48(1984) 323-326.

5) M. Hinai, S. Sawaya and H. Masumoto: J. Japan Inst. Metals 50(1986) 590-593.

6) M. Morita and S. Asano: J. Japan Inst. Metals 65(1993) 10061011.

7) T. Kosugi: Materia Japan 38(1999) 331-339.

8) Y. Bekki and K. Sasaki: Zairyou no Bisaisoshiki to Kinousei, ed. by N. Igata et al., (Japan Society for the Promotion of Science, 133 Committee, 2001) pp. 85-89.

9) A. S. Nowick and B. S. Berry: Anelastic Relaxation in Crystalline Solids, (Academic Press, 1972) pp. 10-23.
10) R. De Batist: Internal Friction of Structural Defects in Crystalline Solids, (North-Holland Publishing, 1972) pp. 36-61.

11) S. Asano: Philos. Mag. 30(1974) 1155-1159.

12) S. Asano: Bulletin Japan Inst. Metals 20 (1981) 21-28.

13) A. K. De, K. De Blauwe, S. Vandputte and B. C. De Cooman: J. Alloys Compd. 310(2000) 405-410.

14) C. Y. Xie, R. Schaller and C. Jaquerod: Mater. Sci. Eng. A252 (1998) 78-84.

15) A. B. Lebedev: Philos. Mag. A74(1996) 137-150.

16) S. Asano: Kinzoku 67 (1997) 21-32.

17) S. Asano: J. Phys. Soc. Jpn. 29(1970) 952-963.

18) A. B. Lebedev: J. de Physique IV 6(1996) C8 255-264.

19) A. Granato and K. Lücke: J. Appl. Phys. 27 (1956) 583-593.

20) S. Asano: Jpn. J. Appl. Phys. 8 (1969) 9-13.

21) T. A. Read: Phys. Rev. 58(1940) 371-380.

22) A. S. Nowick: Progress in Metal Physics, vol. 4 (Pergamon Press, 1953) pp. $12-15$.

23) A. Granato and K. Lücke: J. Appl. Phys. 27 (1956) 789-805.

24) S. Asano, I. Shibahara and T. Obata: J. Phys. Soc. Jpn. 28 (1970) 1091-1092.

25) S. Asano: Bulletin Nagoya Inst. Technol. 23 (1971) 181-189. 